\section{Tydeligere og bedre}

For Tidsskriftets rolle som profesjonell medieaktør var det et viktig skritt da Legeforeningen i 1996 nedfelte i sine lover at det skulle redigeres etter Redaktørplakaten. Den følges av alle profesjonelle norske medier og slår fast at redaktøren skal ha en fri og uavhengig ledelse av redaksjonen og full frihet til å forme mediets meninger, også selv om de i enkelte spørsmål ikke deles av eieren (1).

Et nytt viktig skritt ble tatt da Legeforeningens landsstyre i 2015 nedsatte et utvalg for ytterligere å klargjøre forholdet mellom Tidsskriftet og foreningen som eier (2). Avkledd all jus var utvalgets oppdrag egentlig ganske enkelt: Hva slags organisasjonsstruktur kan best sikre at Tidsskriftet enda tydeligere oppfyller kravene i Redaktørplakaten og anbefalingene til International Committee of Medical Journal Editors, den såkalte Vancouver-erklæringen (3)?

Sikring av redaksjonell integritet er essensielt for enhver profesjonell medieeier. Det må ikke herske tvil om at eieren ikke vil blande seg inn i redaksjonelle avgjørelser. Måten dette er forsøkt løst på i legeforeninger som eier medisinske tidsskrifter er svært ulik. Noen, som den australske legeforeningen, har søkt å skape lengst mulig avstand mellom eier og tidsskrift ved å opprette uavhengige eierselskaper i en aksjeselskapslignende modell. Det har endt med oppsagte redaktører og anklager om utidig eierinnblanding (4). Andre, som den kanadiske legeforeningen, har valgt en modell med tettere strukturell tilknytning, men med mekanismer som skal sikre bedre konflikthåndtering. Det har også endt med oppsagte redaktører og anklager om utidig eierinnblanding (5). Og i noen tidsskrifter er tilknytningen mellom eier og tidsskrift enda tettere. Et eksempel er Annals of Internal Medicine, der sjefredaktøren også er seniorvisepresident i eierorganisasjonen (6).

Spørsmålet om den ideelle eierstruktur lar seg altså ikke besvare enkelt, og utvalget som ble nedsatt av landsstyret måtte gå grundig til verks. Utvalget har bestått av leder av de fagmedisinske foreningene (FaMe) Cecilie Risøe, sentralstyremedlem Cecilie Alfsen, desisorutvalgets leder Gunnar Ramstad, redaksjonskomiteens leder Ola Dale, ansattrepresentant og redaksjonssjef i Tidsskriftet Merete Kile Holtermann, sjefredaktør i det danske Ugeskrift for Loeger Torben Kitaj og jeg som sjefredaktør. I tillegg til de rene utvalgsmøtene har vi hatt møter med administrerende direktør i Fagpressen og generalsekretær i Redaktørforeningen. Vi har innhentet innspill og råd fra redaktørene i JAMA, The Lancet og New England Journal of Medicine og har kartlagt eierskapsstrukturer og organisasjonsmodeller i sammenlignbare norske og utenlandske tidsskrifter.

Forslagene fra utvalget har denne våren vært på høring til alle Legeforeningens foreningsledd og ble deretter enstemmig vedtatt av landsstyret 26. mai 2016. Vedtaket gir en videreføring av dagens modell, med noen viktige justeringer. For det første skal det opprettes et nytt organ - Tidsskriftrådet, som skal bestå av de som til enhver tid innehar vervene som henholdsvis leder av redaksjonskomiteen, leder av de fagmedisinske foreningene og leder av desi- sorutvalget. I tillegg skal Fagpressen og Redaktørforeningen inviteres til å oppnevne en representant hver. Tidsskriftrådet skal ha tre oppgaver: Det skal avgi innstilling ved ansettelse av sjefredaktør, megle i eventuell konflikt mellom eier og sjefredaktør, og årlig evaluere sjefredaktøren etter forhåndsavtalte kriterier. En lignende modell er valgt av flere tidsskrift. Formålet er å sikre redaktøren mot redaksjonell innblanding fra eieren og samtidig sørge for en form for rutinemessig evaluering av hvordan det går med tidsskriftet.

Samtidig tydeliggjøres redaksjonskomiteens rolle som sjefredaktørens rådgiver, ved at myndigheten til å utpeke komiteen flyttes fra sentralstyret til sjefredaktøren. Eieren skal ikke rådgi redaktøren i redaksjonelle spørsmål. Derfor skal ikke lenger generalsekretæren og en representant fra sentralstyret ha plass i komiteen.

Og neste gang det skal ansettes sjefredaktør, er det sentralstyret som skal gjøre det, ikke landsstyret som nå. En eventuell oppsigelse må skje med to tredels flertall og bare etter at Tidsskriftrådet har meglet mellom partene og avgitt innstilling. Disse endringene er betimelige. Både ansettelse og eventuell oppsigelse av sjefredaktøren bør være en grundig og profesjonell prosess. Den kan vanskelig foretas av en forsamling på 145 representanter som møtes én gang i året. I tillegg er det vedtatt endringer i Legeforeningens lover for å lovfeste dagens praksis. Blant annet slås det fast at sjefredaktøren har en fri og uavhengig ledelse av redaksjonen og ikke kan overprøves i redaksjonelle forhold, selv om han eller hun rapporterer til generalsekretæren når det gjelder økonomiske og administrative forhold.

Ingen organisatoriske strukturer kan erstatte et godt og tillitsfullt forhold mellom et tidsskrift og dets eier. Det viser eksemplene fra Canada og Australia med all tydelighet $(4,5)$. Endringene som ble vedtatt på årets landsstyremøte, viser at Legeforeningen fortsatt ønsker å være en profesjonell eier. Det lover godt for et tillitsfullt forhold også i fremtiden, slik at norske leger kan fortsette å være stolte av et tidsskrift med tiltro både nasjonalt og internasjonalt. Resten er opp til dere, som kan bidra som forfattere og fagvurderere i Tidsskriftet, og ikke minst opp til oss i redaksjonen. Vi skal gjøre vårt beste.

\footnotetext{
Litteratur

. Redaktørplakaten. www.nored.no/Redaktoerplakaten/Redaktoerplakaten (14.6.2016).

2. Valeur H. Sikker redaksjonell frihet. Tidsskr Nor Legeforen 2015; 135: 827

3. International Committee of Medical Journal Editors. Recommendations for the Conduct, Reporting, Editing, and Publication of Scholarly work in Medical Journals. www.icmje.org/recommendations/ (14.6.2016).

4. Watch R. Editor of Medical Journal of Australia fired after criticizing decision to outsource to Elsevier. http://retractionwatch.com/2015/05/01/ editor-of-medical-journal-of-australia-fired-after-criticizing-decision-tooutsource-to-elsevier/ (14.6.2016).

5. Smith R. The death throes of national medical journals. The BMJ blogs 2.3.2016. http://blogs.bmj.com/bmj/2016/03/02/richard-smith-the-death-throes-ofnational-medical-journals/ (14.6.2016).

6. American College of Physicians. Meet our 2016-2017 Staff. www.acponline.org/ about-acp/who-we-are/leadership/staff (14.6.2016).
} 